\title{
The Pronunciation of English Low Vowels by Iraqi EFL Learners: An Intralingual Analysis
}

\author{
Ammar A. Al Abdely \\ dr.ammar1974@uoanbar.edu.iq \\ English Language Department, \\ Education College for Women, \\ University of Anbar, Iraq
}

\begin{abstract}
Iraqi EFL learners of English are reported to show accented pronunciation on the segmental level, which might affect their speech intelligibility. This study aimed to identify problems encountered by Iraqi EFL learners in the production of English low vowels and account for them from an intralingual perspective. The study also aimed to identify the effect of Iraqis' English language proficiency level on their pronunciation of English low vowels. Thus, learners were divided into beginners and advanced groups to determine differences between them based on their proficiency level in English. A production test was conducted to identify error patterns of twenty Iraqi EFL learners in producing low vowels. Learners' recordings were acoustically analysed to validate the difficulties identified via the production test. Independent-samples $t$ tests were conducted to identify any significant differences in performance for the two groups. The results showed that learners encountered problems in the production of low vowels,

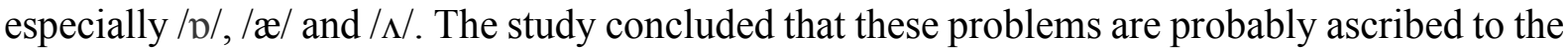
complexities of the L2 vowel space, where vowels are close to each other and thus difficult to produce. Significant differences were identified between the two groups in terms of error means. Nonetheless, the comparison between the vowel chart obtained in this study and the charts offered in previous studies revealed that Iraqi EFL learners are still far from attaining approximant pronunciation. This requires reconsidering current texts, methodologies, and techniques used in teaching English pronunciation to allocate more attention to spectral differences among vowels.
\end{abstract}

Keywords: Low vowels production; Iraqi EFL learners; intralingual analysis; error patterns; acoustic analysis

\section{INTRODUCTION}

Mastering a second language (L2) requires the capability of using the language properly and purposefully (Nair \& Krish, 2021). According to Al Abdely and Thai (2016a), a vital step in acquiring an L2 and using it to communicate is to learn its phonetic system. Correct perception and later correct production of L2 phonemes pave the way to pronouncing L2 phonemes successfully (Baker, 2006). Segmental pronunciations, in general, and vowel pronunciation, in particular, have not been dealt with seriously. The incorrect pronunciation of vowels, which are of high functional load, forming many confusing pairs of words, can seriously affect nonnative speech intelligibility and in turn result in communication breakdown. Vowels pose extraordinary perceptual and articulatory difficulties for ESL/EFL learners of English. Hence, studies on the pronunciation of these vowels with reference to various ESL and EFL learners have become a necessity (Brown, 1988, 1995; Munro \& Derwing, 2008, Oh, 2019; Lee \& Park, 2020; Klimova \& Pikhart, 2021).

Vowels are more difficult to learn than consonants because vowels are phonetically so close to each other in articulation. It becomes even more difficult when considering Received 
Pronunciation English (RPE) low vowels. The area in which low vowels are found is very limited. Actually, they are so close to each other that discriminating one from another is a highly demanding task for EFL learners. Based on Sari (2016, p. 90) "Interference from the student's own language is not the only reason for committing errors. Students may make mistake in the target language, since they do not know the target language very well, they have difficulties in using it". Consequently, an interlingual account of such mistakes is not on its own sufficient to explain pronunciation mistakes. This fact motivates researchers to investigate intralingual errors and interpret them aiming at improving learners' performance in the second or the foreign language. This is one of the reasons behind conducting the present study.

The fact that EFL learners exhibit accented pronunciation is clearly indicative of the difficulties they have encountered in language acquisition (Nikolova, 2010). Accented pronunciation of vowels has been reported in studies on the speech of various ESL/EFL learners such as Mandarins (Rogers \& Dalby, 2005), Koreans and Spaniards (Flege, Bohn \& Jang, 1997), Germans (Bohn \& Flege, 1992), and Arabs (Nikolova, 2010; Almbark, 2012). Accordingly, researches about accented pronunciation are still being conducted with reference to foreign and second language learners in terms of several factors, such as L1 interference, age of learning, length of residence, and experience in the L2.

According to Almbark (2012), learners of English are typically categorized into three main types. The first type includes L2 learners who are lucky enough to acquire the language in a natural setting over a substantial amount of time. The second type includes foreign learners who do not have institutional exposure to the L2, so they lack experience with it. The third and the most important type includes foreign learners who acquire the L2 in a non-native setting, and they are taught by non-native teachers, who are the only models available for their students. The bulk of L2 learners fall under the third type. Millions of EFL learners of English, including the present study's subjects, are taught in their home countries by local teachers. Almbark (2012) states that the third type of learners is the least examined group with regard to L2 or FL pronunciation.

This group of learners often lack the proficiency required to discriminate among 12 sounds; especially the sounds that require a heavy use of spectral cues to be correctly perceived and produced. Schertz, Lotto, and Warner (2015) report that non-native listeners' failure to discriminate among L2 sounds can be the result of lack of sensitivity to the cue that is highly significant for natives. Native listeners, according to Kim, Clayards, and Goad (2017, p. 4), "predominantly use spectral quality while duration has a much weaker effect on their vowel categorization". EFL/ESL learners, on the other hand, rely more on durational cues as they may help L2 learners identify long-short contrasts; especially, if they have these cues in their native language (Schertz et al., 2015). Arabic language has length contrast that distinguishes between short and long vowels, and this length contrast is phonemic. Thus it is a very helpful cue for Arab learners of English in perceiving and producing long vowels. Iraqi learners are not thought to be an exception; hence, they are supposed to identify and produce L2 long vowels easily compared to L2 short vowels (A1 Abdely, 2016).

Based on the results of research piloted by the California State Department of Education (1987), English vowels are believed to be the most difficult phonemes to pronounce. In light of the fact that L1 interference is a prominent factor that affects learning vowels, intralingual analysis can also be helpful in interpreting identified difficulties. Pronunciation errors are mostly motivated by interlingual and intralingual reasons. According to Ali (2015, p. 36), Intralingual errors result "mainly because of the difficulty in the English language". He elaborated that this can happen "to any foreign language speaker". Phonetically, the distance between vowels is usually not large enough for accurate categorization and pronunciation. Marković (2009) indicated that L2 sounds may overlap within the learners' vowel space because of being close to each other. This represents great perceptual and articulatory 
challenges for EFL/ESL leaners. Brown (1988) reported that the inability to differentiate among vowels may have a negative impact on speech intelligibility and can lead to communication inactivity.

\section{INTRALINGUAL EFFECT ON L2 SOUND ACQUISITION}

According to Haryani (2017, p. 86), "To investigate students' errors, it is necessary to decide the sources of errors". In his classification of sources of errors, Brown (1980) identifies four categories:

1. Interference transfer, which refers to the negative interference of the learner's L1.

2. Intralingual transfer, which refers to the negative interference of L2 items themselves.

3. Context of learning, which indicates an overlap between the sources of errors in 1 and 2 , above. In school learning environments, for example, the context of learning may compromise the class, the teacher, and the textbook taught. Several social factors can also be influential in social settings outside the classroom.

4. Communication strategies, which refer to deliberate utilization of verbal strategies to convey an idea or perform a communicative goal when linguistic forms are not available.

However, Brown (2000) points out two basic types of error in terms of source: interlingual and intralingual. Brown (2000) terms interlingual errors as "transfer errors," which result from the learner's lack of knowledge in the L2 or to his/her inability to apply the L2 routine properly (Kavaliauskiene, 2009). Interlingual error analysis is concerned with the native language transfer in the process of L2 learning that results in errors or difficulties. Intralingual errors, Brown (1980) explains, are results of the complexity of the target language. These errors result from learners' failure to adopt the target language system. They do not reflect native language structure, and this is usually caused by overgeneralization because of the lack of target language competence. L1 transfer, according to Sridhanyarat (2018, p.4), "refers to a certain context where a language user transfers some NL rules to their TL counterparts".

Moreover, Erdoğan (2005, p. 266) claims that "intralingual errors occur as a result of learners' attempt to build up concepts and hypotheses about the target language from their limited experience with it". However, the two types of error may overlap in the learner's acquisition process (Haryani, 2017). With regard to pronunciation errors, Stemberger (1989) assumes that these errors may take place due to two reasons, which are learners' inability to perceptually identify sounds or their inability to reproduce the sounds. These reasons can lead to sound substitution, which is assumed to be the most frequent intralingual error committed by Iraqi EFL learners.

Richard (1974) identifies four causes of intralingual error, namely, (1) overgeneralization, (2) ignoring rule restriction, (3) incomplete application of the rules, and (4) the false concept hypothesis (context of learning). Overgeneralization (substitution) and spelling rule confusion are considered to be the two basic types of error in pronunciation (Salwa, 2017; Qaid, 2011).

Most available investigations of pronunciation problems encountered by ESL/EFL learners of English focused on L1 interference in complicating or facilitating the process of learning vowels. Some theories and models have been suggested to explain this interference, such as the Contrastive Analysis Hypothesis (CAH) (Lado, 1957), the Speech Learning Model (SLM) (Flege, 1995), and the Perceptual Assimilation Model (PAM) (Best, 1994, 1995) and the Perception Assimilation Model for L2 (PAM-L2) (Best \& Tyler, 2007). It is true that L1 
interference is a significant potential source of problems for Iraqi EFL learners; consequently, this interference has been investigated in terms of vowel acquisition in studies such as those conducted by Al Abdely and Thai (2016a, 2016b) and Al Abdely, Thai, and Ghani (2016).

Murtiana (2019, p. 208) states that based on Error Analysis Theory presented by Stephen Corder in 1970s, "explanation of errors is the stage where the nature of errors is explained based on particular factor, either interlingual or intralingual. Kaweera (2013, p. 2) reports that interlingual and intralingual effects on learners' L2 performance are highly important to investigate as they do not just provide "insight into how learners learn a second language and the factors that impact that process, but they also provide a better understanding of errors that L2 learners make in the process of second language learning".

Nonetheless, few studies have addressed the interference of the L2 itself in the process of learning, which is often called the intralingual effect. Kurniawan (2018, p. 236) explained that intralingual transfer may result in mistakes "made by the language practitioner because of lack of knowledge of the L2. Lack or incomplete knowledge of L2 makes the disorder appear in the use of language skills". The researcher assumes that pronunciation errors, with substitution errors in focus, made by Iraqi EFL learners of English can be partly explained from an intralingual perspective. Thus, the present study is an endeavour to identify difficulties encountered by Iraqi EFL learners in the pronunciation of English low vowels, and to analyse them through an intralingual analysis that processes data obtained from a production test and an acoustic analysis of EFL learners' recordings.

In EFL context, teachers can benefit from error analysis to identify and explain the difficulties they face in pronunciation. Teachers will employ more effective methods and techniques to enable their students overcome these difficulties. Being aware of the difficulties they face in their quest to learn another language, students will improve better and the learning process can be accelerated and much easier (Frijuniarsi, 2018). The findings of this study and the like, Ali (2015, p. 40) assumes, can lead to the "identification of English vowel areas of which will facilitate communication and so provides a basis for future material planning, design and production".

The present study also aims at detecting any effect of Iraqi learners' English language proficiency level in on their pronunciation of English low vowels and their ability to map them correctly on the vowel chart. The researcher, an instructor of English pronunciation for around 18 years, considers the acquisition of English monophthongs, particularly low vowels, difficult for Iraqi EFL learners. Nonetheless, the present study does not just rely on personal observations or a production test but also on acoustic analysis, which has not been conducted before with reference to Iraqi EFL learners. Hence, the present study aims to fill these gaps in the literature.

\section{STUDIES ON THE PRONUNCIATION OF ARAB LEARNERS OF ENGLISH}

The assumption that Arab EFL learners encounter difficulties in their quest to attain an intelligible L2/FL pronunciation has been well supported in previous studies of L2 acquisition (Flege \& Port, 1981; Joseph \& Odisho 2005; Smith, 2001; Alteyp, 2019; Hamzah, Madbouly, Halim \& Abdullah, 2020). Understandably, most of these studies were much concerned with L1 forms and structures and their negative interference in the process of L2 sound acquisition. Nonetheless, difficulties in L2 acquisition are not essentially the result of L1 transfer, solely. Several other factors have also been investigated in terms of their effects on L2 sound learning.

A number of works concerned with problems faced by Arab EFL or ESL learners of English are found in the literature. Nikolova (2010), for example, explored the effect of L1 on the perception and production of English vowels as spoken by Saudi learners. She showed that Saudi learners encounter major difficulties in the acquisition of English vowels, particularly in 
the acquisition of vowels that are similar in the two languages, as well as the vowels that are not existent in their native language. Almbark (2012) tested the perception and production of Standard Southern British English vowels by Syrian Arabic EFL learners. She concluded that though EFL learners were not equipped with adequate native exposure to the L2, they could still display good skills in some aspects of the target language, including phonology.

Several studies targeted Sudanese Arab EFL learners of English, such as Mohammed (2014), Hassan (2014), and Ali (2013). These studies investigated the performance of learners in the pronunciation of English vowels. Again, L1 interference is the basic motif in these studies, where comparisons are often made between the vowel system of the L1 and the vowel system of the L2. Moreover, Mohammed (2014) stated that Sudanese experience troubles when uttering English letters that are recognized in different ways. The effect of spelling is a basic source of difficulties for Arab learners due to the discrepancy between spelling and pronunciation.

Hubais and Pillai (2010) targeted Omani learners of English, aiming at identifying the difficulties these learners face in the production of English sounds, and pointed out that the Omani speakers produced vowels at similar positions to those of British English vowels; however, different qualities of distinct vowels were still present.

Al Abdely, Thai, and Ghani (2016) investigated the pronunciation of RPE monophthongs by Iraqi EFL learners. They investigated L1 interference and L2 experience effects on the pronunciation of these vowels by Iraqi learners. They collected data from a production test, whose recordings were subjected to experts' rating. They reported that the vowel $/ \mathrm{p} /$ was the most difficult sound followed by $/ æ /$ and $/ \Lambda /$.

The present study is motivated by the results obtained by Al Abdely, Thai, and Ghani (2016), who reported that low vowels were more difficult to pronounce than other vowels; however, it is different from Al Abdely, Thai, and Ghani's (2016) research in combining results from a production test and an acoustic analysis of vowels produced by a different group of Iraqi EFL learners. Acoustic differences that may provide insights into the issue under investigation will be identified to have a better understanding of the difficulties Iraqi learners face. Hence, this study offers an intralingual analysis of these difficulties. Moreover, the present study targets a different group of Iraqi EFL learners, which offers a chance to validate the results of the study mentioned above. The study also tries to validate the null hypothesis that there is no difference in Iraqi EFL learners' pronunciation of English low vowels based on their level of proficiency in English.

The present study attempts the following questions:

1. What are the problems encountered by Iraqi EFL learners in the production of English low vowels?

2. To what extent intralingual analysis can account for the problems encountered by Iraqi EFL learners in the production of English low vowels?

3. Is there any effect of English language proficiency level on Iraqi EFL leaners' production of English low vowels?

\section{RPE MONOPHTHONGS}

RPE is used in this study as a model of analysis as it is adopted as the accent taught to EFL learners all over the world, and Iraqi EFL learners are not an exception in this respect. Iraqi EFL learners in all English language departments in Iraqi universities are taught this accent. Textbooks of phonetics and phonology used in Iraqi universities offer accounts of RPE and teach learners the phonemes of RPE. Nevertheless, this study is not an invitation to learners to adopt this particular accent of English. 
Below, is a brief account of RPE low vowels as presented by Roach (2004).

1. /æ/ is front and open (e.g., bat, man, gas) with slightly spread lips.

2. $/ \Lambda /$ is central and open with lips in neutral position (e.g., but, some, rush).

3. $/ \mathrm{p} /$ is not quite fully back and between open and mid with the lips slightly rounded (e.g., pot, gone, cross).

4. /a:/ is open and back with a neutral lip position. (e.g., cart, pass, hard)

Figure 1 is the RPE vowel chart presented by Roach (2004). It specifies the precise location of the short and long vowels of RP English with low vowels framed with a different colour.

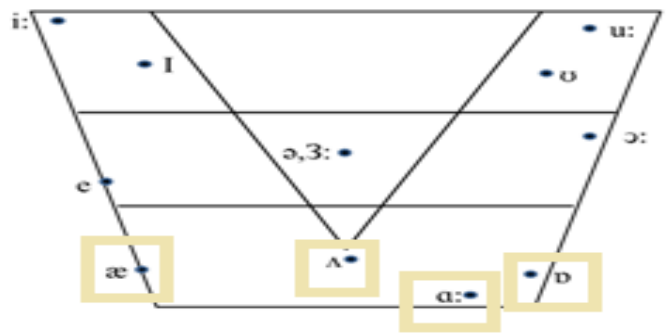

FIGURE 1. RPE simple vowels

To compare between the formants obtained from the results of the acoustic analysis conducted in the present work and low vowel formants offered by previous related studies, the means of low vowel formants of the present study and the means obtained from previous studies, namely, Wells (1962), Henton (1983), and Deterding (2006), were plotted on the vowel space via Praat. The chart presented in Roach (2004) will not be included in this comparison as the frequencies used for mapping the vowels are not available. As for the other studies, frequencies are available and the researcher could map them on vowel charts using Praat. Mapping the frequencies using the same software program with the same specifications will eliminate any effect of possible technical differences on the accuracy of these charts and the argument made based on them. The following charts (Figures 2-4) plot the vowel formants provided in Wells (1962), Henton (1983), and Deterding (2006), respectively.

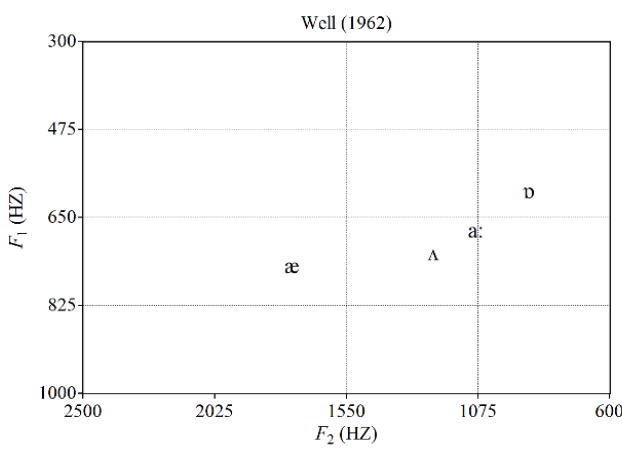

FIGURE 2. F1 and F2 (Wells, 1962)

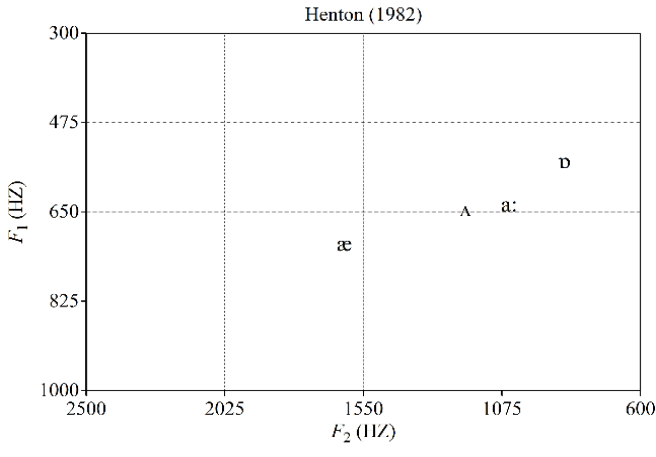

FIGURE 3. F1 and F2 (Henton, 1983) 


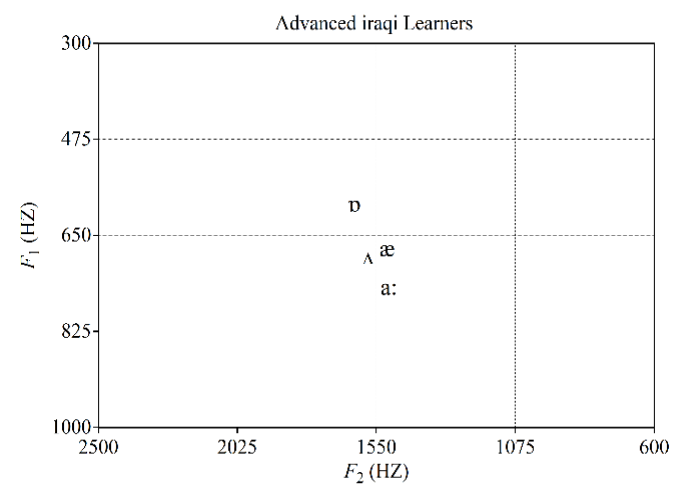

FIGURE 4. $\mathrm{F}_{1}$ and $\mathrm{F}_{2}$ (Deterding, 2006)

\section{METHODOLOGY}

\section{SAMPLES AND LOCATION OF THE STUDY}

Twenty Iraqi EFL learners were selected from among 50 informants who were asked to respond to a demographic questionnaire that aims to make sure the sample recruited is suitable for the study purposes. Based on the results of the questionnaire, some informants were eliminated as they speak a different Iraqi accent, have previous exposure to English in a native setting, or have a third language such as Kurdish. The production test included 25 students; however, only the recordings of twenty students were analysed due to technical problems in some recordings. Some informants were shy or very hesitant; hence, their pronunciation was not clear and unmeasurable. The researcher finally selected 20 informants only so as to have an equal number of informants in each group. The selected informants were recorded at the University of Anbar, Education College for Women, English Language Department. The production test was conducted in quiet halls using noise cancelling microphones. The informants were students majoring in English language and its literature. They were divided into two groups, beginners (A) and Advanced (B), based on their performance in a general English proficiency test. Having the study informants divided into two groups based on their general proficiency level in English was meant to identify any differences in the pronunciation of informants that can be ascribed to their proficiency level in English. This grouping also helped tracing the pronunciation development in terms of difficulty rank order, nature of error patterns, and vowel mapping. The informants" first language was Arabic, and their native accent was Baghdadi Arabic. Their ages ranged from 20-28, and they had no previous chance of living in an Englishspeaking country. They all volunteered to participate in the study and signed a consent letter certifying that.

\section{DATA COLLECTION METHOD}

The data used in this study were collected from a production test conducted on twenty Iraqi EFL learners. They were required to pronounce a list of 12 words that carry the four RPE low vowels three times each. This will offer an overall number of 60 trials for each vowel. F1 and F2 means for each vowel were taken from these three instances. All of these trials are analysed so that more consistent results can be obtained, and more authentic conclusions can be drawn from the analysis. The words chosen to be the stimuli of this study were frequently used words that are most probably known by students at the university level. They are one syllable words that show the targeted vowels in one syllable so as not to confuse learners with other vowels in the same word. The wordlist used as the stimuli in this study is provided in Table 1 below: 
TABLE 1 . Words used in the production test

\begin{tabular}{|c|c|c|}
\hline Vowels & Words & Transcription \\
\hline$/ \mathfrak{a} /$ & $\begin{array}{l}\text { Cap } \\
\text { Hat } \\
\text { Lack }\end{array}$ & $\begin{array}{l}\text { /kæp/ } \\
\text { /hæt/ } \\
\text { /læk/ }\end{array}$ \\
\hline$/ \mathrm{N} /$ & $\begin{array}{l}\text { Duck } \\
\text { Ton } \\
\text { Lust }\end{array}$ & $\begin{array}{l}/ \mathrm{d} \Lambda \mathrm{k} / \\
/ \mathrm{t} \Lambda \mathrm{n} / \\
/ 1 \mathrm{st} /\end{array}$ \\
\hline$/ \mathbf{p} /$ & $\begin{array}{c}\text { Wad } \\
\text { Lock } \\
\text { Cot }\end{array}$ & $\begin{array}{l}/ \mathrm{w} \mathbf{w} d / \\
/ \mathrm{l} \mathbf{p k} / \\
/ \mathrm{kw} t /\end{array}$ \\
\hline$/ \mathbf{a}: /$ & $\begin{array}{l}\text { Last } \\
\text { Heart } \\
\text { Hard }\end{array}$ & $\begin{array}{l}\text { /la:st/ } \\
\text { /ha:t/ } \\
\text { /ha:d/ }\end{array}$ \\
\hline
\end{tabular}

The production test was designed using Praat version 6.0.55 (Boersma \& Weenink, 2019). The participants were shown words embedded in the carrying sentence "I am saying the word ........." on a computer screen. Participants were required to pronounce each sentence within five seconds. The pronunciations of the informants were recorded automatically and extracted into data files comprising audio files of each informant separately listed in sub-files. The targeted words were later extracted from the complete sound wave file, and then the targeted vowels were extracted to be processed for the measurement of their frequencies.

\section{DATA ANALYSIS METHOD}

The audio files extracted from the production test were processed in two different ways, which were used collaboratively to provide an integrated picture of the difficulties encountered by Iraqi EFL learners in the pronunciation of RPE low vowels. The first step in this process was to edit the audio files so that only the targeted words are extracted in separate files to be given to two raters, who were experts in teaching English phonetics and phonology in the University of Anbar. The three repetitions of each word as produced by informants were all sent to raters to listen to and give their judgments on. These raters were asked to listen to the pronunciation of the informants and give their judgments on whether the pronunciations of low vowels were correct or not. Raters were also recommended to give the vowel symbol that best represents the vowel sound they hear. The researcher provided raters with a scoring sheet (rubric) based on which they should give their judgments. This scoring sheet was adapted from Al Abdely (2016) to include English low vowels only. Raters were also provided with a key table that provided the IPA symbols of RPE low vowels with one example for each vowel (Appendix). The ratings were measured for reliability, and they were found highly reliable with a Cronbach's alpha result of .864 .

The ratings were used first to identify the difficulties encountered in the pronunciation of these vowels in terms of difficulty rank order. Second, the ratings were also used to identify error patterns shown by informants. As raters were asked to identify the vowel sound produced in each word, the researcher was able to create a confusion matrix that shows the vowel produced instead of the one intended. This was very important to identify the possible intralingual effect on informants' performance as it helped show vowel substitutions made by informants. Error means were also used to verify the null hypothesis of no significant difference in the means of beginners and advanced learners in the pronunciation of low vowels based on their English language proficiency level. To accomplish this, four independent-samples $t$-tests 
were performed. The independent variable in this analysis was language proficiency level, and the dependent variable was learners' error means.

The audio files were also acoustically analysed for vowel formants using Praat version 6.0.55. $F_{1}$ and $F_{2}$ values for the low vowels were measured and mapped in two vowel charts as they were pronounced by learners of the two groups. These vowel charts were compared to identify any improvement in the pronunciation of low vowels. A unified chart that maps the overall formant means was compared to vowel charts provided in Wells (1962), Henton (1983), and Deterding (2006) to identify if low vowel formants produced by Iraqi learners approximated the formants offered in these studies. These studies analysed native speakers' pronunciation of individual vowels (in isolation) as in (Wells, 1962), while in Henton (1983) and Deterding (2006) the vowels recorded were in connected speech. This comparison together with the results of ratings were to be used for identifying the difficulties encountered by the study informants and offer insights on how to overcome these difficulties.

\section{RESULTS AND DISCUSSION}

\section{RATING RESULTS}

Based on the judgments given by raters, error counts and error rates were obtained to identify the level of difficulty encountered in the pronunciation of low vowels. Moreover, a confusion matrix outlining error patterns shown in the pronunciation of these vowels was also made.

Table 2 shows the overall counts of errors made by learners in the pronunciation of low vowels. As shown in the table, the vowel / $\mathrm{p} /$ was the most difficult to pronounce followed by the vowel /æ/ with which learners seemed to have considerable difficulties, as well. The vowel $/ \Lambda /$ was also somehow difficult with a $48.33 \%$ error percentage. The vowel /a:/ seems to have been easier than other low vowels, with a lower error percentage.

TABLE 2. Rank order, error counts, and error percentages of low vowel pronunciation

\begin{tabular}{|c|c|c|c|}
\hline Rank & Vowel & $\begin{array}{c}\text { Error Counts } \\
\text { N trial } 240 \text { (60 for each vowel) }\end{array}$ & Error Percentage \\
\hline 1 & $/ \mathrm{d} /$ & 40 & $66.66 \%$ \\
\hline 2 & $/ æ /$ & 33 & $55 \%$ \\
\hline 3 & $/ \Lambda /$ & 29 & $48.33 \%$ \\
\hline 4 & /a:/ & 8 & $13 \%$ \\
\hline Total & & 110 & $45.83 \%$ \\
\hline
\end{tabular}

Table 3 offers a confusion matrix, which shows the patterns of errors committed by learners in the pronunciation of low vowels. Learners showed systematic behaviour in terms of the vowels produced instead of the targeted ones. The vowels $/ \mathrm{p} /$ and $/ \Lambda /$ were mispronounced, exchanging one for another, and the vowel $/ \mathfrak{æ} /$ was mostly produced as $/ \Lambda /$. However, the vowel /a:/ was often pronounced as the mid, long vowel/e:/.

TABLE 3. Confusion matrix of RPE low vowels

\begin{tabular}{lcc}
\hline No & Vowel & $\begin{array}{c}\text { Most produced } \\
\text { as }\end{array}$ \\
\hline $\mathbf{1}$ & $/ \mathrm{d} /$ & $/ \Lambda /$ \\
$\mathbf{2}$ & $/ \mathfrak{a} /$ & $/ \mathrm{\Lambda} /$ \\
$\mathbf{3}$ & $/ \Lambda /$ & $/ \mathrm{J} /$ \\
$\mathbf{4}$ & $/ \mathrm{a}: /$ & $/ \mathrm{e}: /$ \\
\hline
\end{tabular}




\section{ACOUSTIC RESULTS}

The formants of the low RPE vowels were extracted from the pronunciation of Iraqi EFL learners. The $F_{1}$ and $F_{2}$ formants were measured using Praat. Table 4, below, shows overall $F_{1}$ and $F_{2}$ results for the four RPE low vowels as pronounced by Iraqi EFL learners examined in this study.

TABLE 4. $F_{1}$ and $F_{2}$ for RPE low vowels

\begin{tabular}{ccc}
\hline & $\boldsymbol{F}_{\mathbf{1}}$ & $\boldsymbol{F}_{\mathbf{2}}$ \\
\hline$/ \mathfrak{a} /$ & 738 & 1560 \\
$\mathrm{ha} /$ & 771 & 1575 \\
$\mathrm{/ \textrm {w }} /$ & 668 & 1598 \\
$/ \Lambda /$ & 738 & 1584 \\
\hline
\end{tabular}

Table 5 shows the formant means of the four low vowels as pronounced by the two groups labelled as advanced (A) and beginners (B), respectively.

TABLE 5. $F_{1}$ and $F_{2}$ of low vowels for the two groups

\begin{tabular}{ccccc}
\hline & \multicolumn{1}{c}{} & \multicolumn{2}{c}{ B } & $\boldsymbol{F}_{\mathbf{2}}$ \\
\hline /æ/ & $\boldsymbol{F}_{\mathbf{1}}$ & $\boldsymbol{F}_{\mathbf{2}}$ & 675 & 1513 \\
/a:/ & 802 & 1606 & 745 & 1507 \\
/ $/$ & 798 & 1643 & 593 & 1624 \\
$/ \mathrm{s} /$ & 743 & 1572 & 689 & 1578 \\
\hline
\end{tabular}

To test the hypothesis that beginners and advanced Iraqi EFL learners are associated with statistically significant means of $F_{1}$ and $F_{2}$ low vowel formants, four independent-samples $t$-tests were conducted. Data normality and homogeneity were both validated for the independent $t$-tests with skew $<|2.0|$ and kurtosis $<|9.0|$, and $F>0.05$ level. The results of the four independent-samples $t$-tests conducted to identify significant differences in the $F_{1}$ and $F_{2}$ means due to their proficiency level in the L2 are provided in Table 6Error! Reference source not found., below.

TABLE 6. Results of independent-samples $t$-tests

\begin{tabular}{cccccc}
\hline \multicolumn{5}{c}{$\begin{array}{c}\text { Levene's Test for Equality of Variances } \\
\text { Independent-Samples }\end{array}$-Tests } \\
\hline Vowel & $\boldsymbol{F}$ & Sig. & $\boldsymbol{t}$ & $\boldsymbol{d} \boldsymbol{f}$ & Sig. (2-tailed) \\
\hline /æ/ & 2.107 & .164 & 2.687 & 18 & $\mathbf{. 0 1 5}$ \\
& & & 2.687 & 14.925 & $\mathbf{. 0 1 7}$ \\
/a:/ & 2.396 & .139 & 1.092 & 18 & .289 \\
& & & 1.092 & 15.603 & .292 \\
/p/ & 1.639 & .217 & 3.278 & 18 & $\mathbf{. 0 0 4}$ \\
& & & 3.278 & 16.962 & $\mathbf{. 0 0 4}$ \\
/ $/$ & .049 & .828 & 2.609 & 18 & $\mathbf{. 0 1 8}$ \\
& & & 2.609 & 18.000 & $\mathbf{. 0 1 8}$ \\
\hline
\end{tabular}


As shown in Error! Reference source not found., statistically significant differences were reported in the formants of the vowels $/ \mathfrak{x} /, / \mathrm{p} /$, and $/ \mathrm{N} /$ at the $<0.05$ level. On the other hand, no significant difference was identified in the formants of the vowel /a:/ at the $>0.05$ level. So, the null hypothesis that there is no difference in the performance of beginners and advanced learners based on proficiency level is accepted with regard to the vowel /a:/, yet the null hypotheses with regard to the vowels $/ æ /, / \mathrm{p} /$, and $/ \Lambda /$ are ejected. The significant difference revealed in the performance of the two groups does not necessarily mean that the advanced group did better than the beginners' group. Moreover, it does not indicate the nature of this difference. Hence, the $F_{1}$ and $F_{2}$ results obtained from the Iraqi learners' pronunciations needed to be plotted on the vowel chart to uncover the nature and importance of this difference.

Figure 5Error! Reference source not found. shows the vowel charts drawn in Praat based on the vowel formants of learners from the advanced and beginners' groups. The chart on the left (a) is for the advanced learners and the chart on right (b) is for beginners.

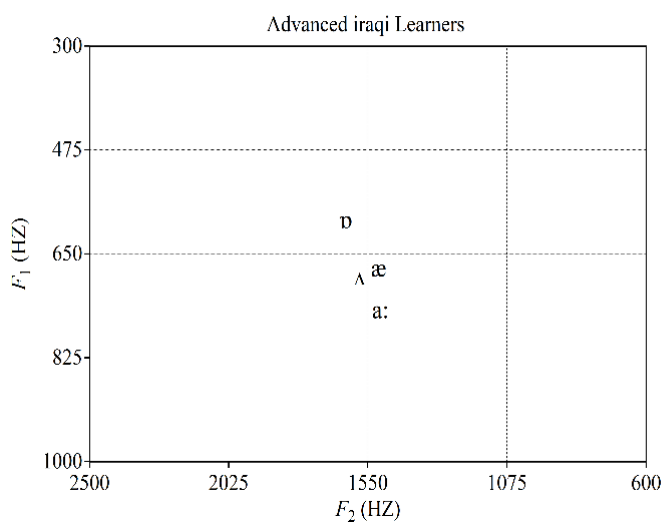

(a)

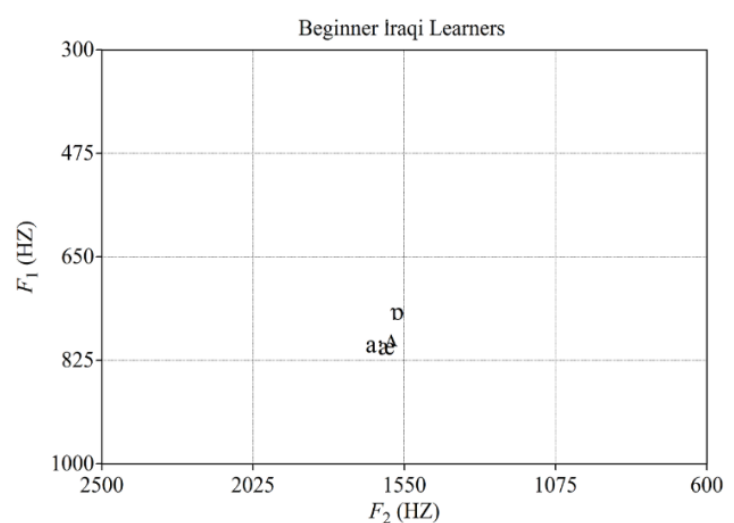

(b)

FIGURE 5. Vowel charts based on advanced (a) and beginners' (b) formants, respectively

It is clear from the distribution of low vowels in the two charts that both beginners and advanced learners, but especially beginners, were unable to discriminate among low vowels. Beginners produced at least three vowels in very similar or exact positions. However, it can be noticed that advanced learners discriminated among low vowels in a somewhat better way, as indicated in Error! Reference source not found., above. This result agrees with the results obtained from the independent-samples $t$-tests discussed above. A sort of improvement in the pronunciation of RP English low vowels due to higher proficiency level in the L2 can be identified. Figure 6 is a chart that plots overall $F_{1}$ and $F_{2}$ values for both beginners and advanced Iraqi learners for comparison with other charts proposed in previous studies.

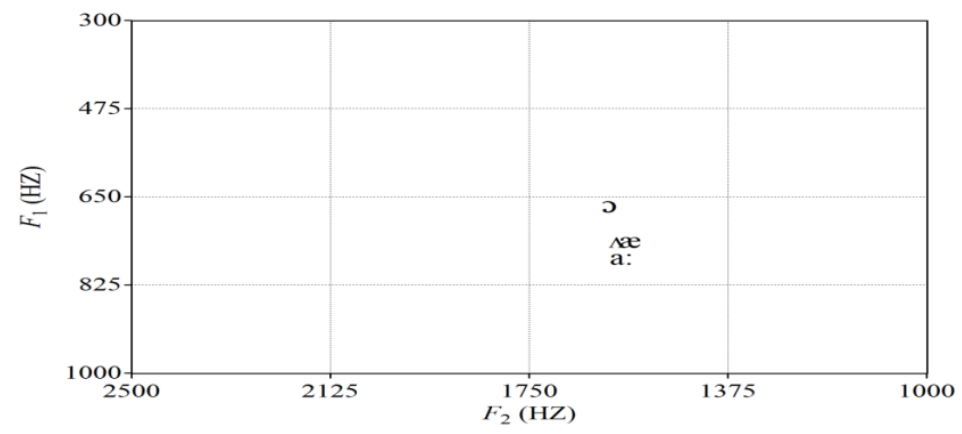

FIGURE 6. Vowel chart of RPE low vowels as produced by beginner and advanced Iraqi learners 
As seen in the chart above, low vowels are mapped in a very limited area of the vowel space. The distance between them is very short, which is not the case in the vowel chart of RPE vowels. This also hints to the nature of problems Iraqi EFL learners encounter in the pronunciation of RPE low vowels. The chart also confirms the patterns of errors provided in the confusion matrix (Error! Reference source not found.), where low vowels were often pronounced in place of one another. This confirms Iraqi learners' inability to discriminate among these vowels. They still lacked the spectral knowledge that would enable them to do so.

The first two charts above are very much alike in terms of the position of low vowels with very slight differences in their $F_{1}$ and $F_{2}$ values. However, the chart drawn based on Deterding (2006) shows a transition in the low vowels to the centre of the chart, where they become closer to each other, yet each vowel still has a distinct position that is unlikely to be mistaken for another vowel. The chart (Figure 6) that plots vowel formants as produced by Iraqi EFL learners of English is obviously different from the other charts, especially the first two of Well (1962) (Figure 2), and Henton (1983) (Figure 3). Nevertheless, this chart confirms the transition shown by Deterding (2006) (Figure 4) even though the vowel positions still reflect Iraqi EFL learners' inability to discriminate among these vowels.

\section{DISCUSSION}

The rating results confirm difficulties encountered by Iraqi EFL learners in the pronunciation of RPE low vowels. The most difficulty was encountered in the vowels $/ \mathrm{p} /, / \mathfrak{m} /$, and $/ \mathrm{N} /$, respectively, while the vowel /a:/ was comparatively much easier. This can be explained from an interlingual perspective as Arab learners in general and Iraqis in particular are thought to use durational cues more effectively than spectral cues. In their experimental study, AsSammer and Yousif (2015) concluded that Iraqi EFL learners of English show better production abilities of long vowels (71\%) compared with short vowels (63\%). Moreover, $\mathrm{Al}$ Abdely (2016) states that Iraqi learners encountered more difficulty in identifying and producing the vowels that share some spectral features but differ in some others. That is why they can pronounce long vowels more accurately than short vowels, whose pronunciation requires employing spectral/acoustic cues. Though this assumption has not been experimentally tested in the present work, it is supported by findings concluded in several previous studies. Of them is Ali's (2013), which affirms that English tense-lax vowels posed no serious problems to Arab Sudanese EFL learners of English, possibly due to correspondence with the English and Arabic long/short vowel distinction. Studies on other Arab learners such as Jordanian and Saudi EFL learners of English also reports that learners transfer length contrast found in Arabic to their English vowels (Flege \& Port, 1981; Mitleb, 1984). These results confirm the ones obtained in previous studies such as Al Abdely and Thai (2016a), who also found that the pronunciation of short vowels is much more difficult than that of long vowels.

From an intralingual point of view, RPE Low vowels are located in a crowded area, where they are very close to each other, which makes their identification and their pronunciation a difficult job on the part of EFL learners. Fox and Jacewicz $(2019,874)$ report that "perceptual separation of mid and low vowels is more challenging than separation of high and mid vowels, which is also reflected in the increased number of confusions with the neighbors". Learners may not be able to discriminate these vowels from one another as these vowels have several spectral features in common. This has been confirmed by Best (1995), who assumes the standpoint that the level of troubles learners may experience in the discrimination of L2 phonemes can be predicted on the basis of the observed phonetic distance between L1 and L2 phones. However, Best (1995) elaborates that this is not always the result 
of overlapping L1 and L2 vowel spaces; it can rather be phonetically explicated since the phonetic distance between L2 vowels themselves is commonly not large enough for correct discrimination. More specifically, Iraqi EFL learners of English try to reproduce the target sounds based on their limited experience with these sounds. Accordingly, they tend to substitute one target sound with another. Shahidi, Aman, and Kechot (2012, p. 1110) confirm that the "analysis of L1 and L2 at a phonemic level provides only a partial view of deeper relationships between languages in contact".

Similarly, Marković (2009) reports that L2 phonemes may overlap within the vowel space of learners as they are so close to each other. This denotes excessive perceptual and articulatory challenges for leaners. The patterns of errors shown by the informants of this study indicate the assumption that the more distance between vowels, the easier their pronunciation would be. Similarly, the least distance between vowels, the more difficult its pronunciation would be (Flege, 1995). The spectral similarities among these vowels make the task of discriminating them from one another a demanding one, a task that requires heavy practice using minimal pairs that include these vowels. The error patterns identified in this study show that learners often mispronounce a vowel with one of the vowels that are very close to it.

More specifically, learners are thought to be overgeneralizing, meaning they substitute one low vowel for another low vowel. Only the long vowel /a:/ was misproduced as /e:/, which is not a low vowel. However, the number of errors committed in the pronunciation of this vowel was very much lower compared to other low vowels. Iraqi EFL learners of English tend to substitute L2 vowels rather than producing non-existent or L1 sounds. These substitution instances most probably occur as a result of the inadequate knowledge these learners possess about L2 vowels.

Acoustically, the mapping of low vowels confirms the difficulties faced by Iraqi EFL learners as the positions of the four vowels in the chart are interestingly very close. As shown in Error! Reference source not found., above, low vowels are located in a limited, crowded area. This means that learners are unable to discriminate among these vowels, and this explains the high error percentages reported and the error patterns identified. It can be observed here that the results of the rating analysis and the acoustic analysis do match as they refer to similar areas of difficulties. Furthermore, the nature of the difficulties and the error patterns identified in this study confirm and validate the results obtained by Al Abdely and Thai (2016a).

\section{CONCLUSION}

It can be concluded that Iraqi EFL learners encounter considerable difficulties in the pronunciation of RPE low vowels. More specifically, they are not good at using the acoustic features that help discriminate one vowel from another. This may be ascribed to their limited proficiency in L2. This was evident in the higher level of difficulty encountered by Iraqi learners in producing short vowels. Learners' limited exposure to the L2 is not helpful enough to attain nativelike pronunciation of short vowels, which have been reported to be more difficult than long vowels. Nevertheless, learners are good at employing durational cues when it comes to long vowels making use of the long-short phonemic contrast they have in their L1. The informants of this study often mispronounced low vowels in place of one another. This is due to the fact that low vowels share similar spectral cues and are located in a limited space. The distance between these vowels is too short to allow correct pronunciation. These results stress the negative effect of L2 complexities on L2 phoneme acquisition. Learners tend to substitute vowels with each other, and this is an intralingual error often committed due to L2 complexities, which learners fail to deal with as they are not skilful enough in this respect. This requires learners, teachers, and textbook designers to present these vowels in pairs to emphasize the differences between them. The acoustic analysis conducted in this study confirms the 
results obtained from the production test. The patterns of errors identified are very well justified in the mapping of low vowel formants on the vowel chart. The vowel chart of low vowels predicts that learners will have such difficulties and manifest such error patterns. Teachers are also invited to raise their students' awareness of the similarities and differences among L2 phonemes. Teachers of English pronunciation should not confine their attention to the description of vowels, ignoring their relationships in the vowel space. Deductive teaching of interlingual errors and inductive teaching of intralingual errors might efficiently decrease EFL learners' errors.

\section{REFERENCES}

Al Abdely, A. A. (2016). Perception and Production of English Vowels by Native Iraqi Arabic learners. Unpublished Ph.D thesis, Universiti Putra Malaysia, Serdang, Malaysia.

Al Abdely, A. A. W., \& Thai, N. T. (2016a). Learning English vowels by Iraqi EFL learners: Perceived difficulty versus actual performance. 3L: Language, Linguistics, Literature, 22(1), 1-18.

Al Abdely, A. A. W., \& Thai, N. T. (2016b). The interrelation between the perception and production of English monophthongs by speakers of Iraqi Arabic. Pertanika Journal of Social Sciences and Humanities, 24(S), 1-10.

Al Abdely, A., Thai, Y. N., \& Ghani, C. A. A. (2016). The pronunciation of English monophthongs by Iraqi EFL learners. International Journal of Advanced Research and Review, 1(6), 94-114.

Ali, E. M. T. (2013). Pronunciation problems: Acoustic analysis of the English vowels produced by Sudanese learners of English. International Journal of English and Literature, 4(10), 495-507.

Ali, E. M. T. (2015). The elimination of pronunciation problems of English vowels of Saudi students of English resulting from complex letter-sound relationship. International Journal of Language and Literature, 3(1), 35-4.

Almbark, R. (2012). The perception and production of SSBE vowels by Syrian Arabic learners: The foreign language model. Unpublished Ph.D thesis, University of York, York, England.

Alteyp, O. A. A. (2019). Interference of Phonological Aspects of Emphatic Consonant Sounds from Arabic into English Consonant Sounds for Sudanese University Students of English. International Journal of Applied Linguistics and English Literature, 8(5), 1026.

As-Sammer, M. A. A. S., \& Yousif, N. S. (2015). The Correlation between Vowel Production and Vowel Perception as Elicited in the Performance of Adult Iraqi Learners of English: Acoustic Perspective. ADAB AL-BASRAH, 72, 1-30.

Baker, A. (2006). Ship or sheep? Student's book: An intermediate pronunciation course. Cambridge, England: Cambridge University Press.

Best, C. T. (1994). The emergence of native-language phonological influences in infants: A perceptual assimilation model. In J. Goodman \& H. C. Nusbaum (Eds.), The development of speech perception: The transition from speech sounds to spoken words (pp. 167-224). Cambridge, MA: MIT Press.

Best, C. T. (1995). A direct realist view of cross-language speech perception. In W. Strange (Ed.), Speech perception and linguistic experience: Issues in cross-language research (pp. 171-206). Baltimore, MD: York Press.

Best, C. T., \& Tyler, M. D. (2007). Nonnative and second-language speech perception: Commonalities and complementarities. In M. J. Munro \& O. S. Bohn (Eds.), The role 
of language experience in speech learning (13-34). Amsterdam, Netherlands: John Benjamins.

Boersma, P., \& Weenink, D. (2019). Praat: Doing phonetics by computer (Version 6.0.55) [Computer program]. Retrieved from https://www.praat.org/

Bohn, O. S., \& Flege, J. E. (1992). The production of new and similar vowels by adult German learners of English. Studies in Second Language Acquisition, 14(02), 131-158

Brown, A. (1988). Functional load and the teaching of pronunciation. TESOL Quarterly, 22(4), 593-606.

Brown, A. (1995). Minimal pairs: Minimal importance? ELT Journal, 49(2), 169-175.

Brown, H. D. (1980). Principles of language learning and teaching. Upper Saddle River, NJ: Prentice Hall Inc.

Brown, H. D. (2000). Principles of language learning and teaching (Vol. 4). New York, NY: Longman.

Deterding, D. (2006). The North Wind versus a Wolf: short texts for the description and measurement of English pronunciation. Journal of the International Phonetic Association, 36(2)187-196.

Erdoğan, V. (2005). Contribution of error analysis to foreign language teaching. Mersin Üniversitesi Ĕ̈itim Fakültesi Dergisi, 1(2), 1-10.

Flege, J. E. (1995). Second language speech learning: Theory, findings, and problems. In W. Strange (Ed.), Speech perception and linguistic experience: Issues in cross-language research (233-277). Timonium, MD: York Press.

Flege, J. E., Bohn, O. S., \& Jang, S. (1997). Effects of experience on non-native speakers' production and perception of English vowels. Journal of Phonetics, 25(4), 437-470.

Flege, J. E., \& Port, R. (1981). Cross-language phonetic influence: Arabic to English. Language and Speech, 24(2), 125-146.

Fox, R. A., \& Jacewicz, E. (2019). Perceptual separation of spectrally overlapping vowels. In Proceedings of the 19th International Congress of Phonetic Sciences, 874-878.

Frijuniarsi, N. (2018). Error in Vowel Pronunciation Made by Informatics Students. Journal of English Language Teaching, 2(2), 149-159.

Hamzah, M. H., Madbouly, A. E. S., Halim, H. A., \& Abdullah, A. H. (2020). The production of the English stop voicing contrast by Arab L2 speakers of English. Indonesian Journal of Applied Linguistics, 10(2), 434-444.

Haryani, T. R. (2017). Investigating pronunciation error produced by English department students of UNISLA. In Proceedings of International Seminar on Literacy Awareness in Shaping Citizen Character. Lamongan (pp. 85-89).

Hassan, E. M. I. (2014). Pronunciation problems: A case study of English language students at Sudan University of Science and Technology. English Language and Literature Studies, 4(4), 1-14.

Henton, C. G. (1983). Changes in the vowels of received pronunciation. Journal of Phonetics, 11(4), 353-371.

Hubais, A., \& Pillai, S. (2010). An instrumental analysis of English vowels produced by Omanis. Journal of Modern Languages, 20(1), 1-18.

Joseph, M., \& Odisho E. (2005). Techniques of teaching comparative pronunciation in Arabic and English. Piscataway, NJ: Gorgias Press LLC.

Kavaliauskienè, G. (2009). Role of mother tongue in learning English for specific purposes. ESP World, 8(1), 2-8.

Kaweera, C. (2013). Writing Error: A Review of interlingual and intralingual interference in EFL context. English language teaching, 6(7), 9-18.

Kim, D., Clayards, M. \& Goad, H. (2017). Individual differences in second language speech perception across tasks and contrasts: The case of English vowel contrasts by Korean 
learners. Linguistics Vanguard, 3(1), 20160025. https://doi.org/10.1515/lingvan2016-0025

Klimova, B., \& Pikhart, M. (2021). New Advances in Second Language Acquisition Methodology in Higher Education. Education Sciences, 11(3), 128.

Kurniawan, M. (2018). the Analysis of interlingual and intralingual interference in children's literature translation project. Celt: A Journal of Culture, English Language Teaching \& Literature, 18(2), 229-244.

Lado, R. (1957). Linguistics across cultures: Applied linguistics for language teachers. Anarbor, MI: University of Michigan Press.

Lee, O. S., \& Park, J. (2020). Understanding L2 Speech Production: Implications for Teaching Speaking in EFL Classroom. The Journal of AsiaTEFL, 17(3), 808-823.

Marković, M. (2009). The perception and production of the English vowels /e /and /æ/ by native speakers of Serbian. Paper presented at the 18th International Symposium of Theoretical and Applied Linguistics, Thessaloniki, May.

Mitleb, F. (1984). Vowel length contrast in Arabic and English - A spectrographic test. Journal of Phonetics, 12(3), 229-235.

Mohammed, F. E. (2014). The role of first language in learning English as a foreign language in Sudan. International Journal of English and Education, 3(2), 274-281.

Munro, M. J., \& Derwing, T. M. (2008). Segmental acquisition in adult ESL learners: A longitudinal study of vowel production. Language Learning, 58(3), 479-502.

Murtiana, R. (2019). An analysis of interlingual and intralingual errors in EFL learners' composition. Jurnal Educative: Journal of Educational Studies, 4(2), 204-216.

Nair, P. K., \& Krish, P. (2021). Mother Tongue Interference in English Writing among Tamil School Students. GEMA Online ${ }^{\circledR}$ Journal of Language Studies, 21(1), 110-123.

Nikolova, A. (2010). L1 influence in the perception and production of English vowels by Arabic speakers. Unpublished Ph.D thesis, Alliant International University, California, USA.

Office of Bilingual Bicultural Education. (1987). Handbook for teaching Japanese-speaking students. Sacramento, CA: California State Department of Education. Retrieved from https://files.eric.ed.gov/fulltext/ED287316.pdf.

Oh, E. (2019). The relationship between" native-like" L2 vowel production and perceptual judgments enhancement by native listeners. Linguistic Research, 36(2), 241-261.

Qaid, Y. A. (2011). Analysis of intralingual errors in learning English as a foreign language by Yemeni students. Language in India, 11(5), 534-545.

Richard, J, C. 1974. Error analysis: Perspective on second language acquisition. London, England: Longman Group Ltd.

Roach, P. (2004). British English: Received pronunciation. Journal of the International Phonetic Association, 34(02), 239-245.

Rogers, C. L., \& Dalby, J. (2005). Forced-choice analysis of segmental production by Chinese-accented English speakers. Journal of Speech, Language, and Hearing Research, 48(2), 306-322.

Salwa, S. (2017). Analysis of interlingual errors in pronunciation made by the fifth semester students of English education study program at UIN Raden Fatah Palembang Unpublished Bachelor thesis, State Islamic University, Raden Fatah Palembang, Indonesia.

Shahidi, A. H., Aman, R., \& Kechot, A. S. (2012). Production and perception of English word final stops by Malay speakers. GEMA Online ${ }^{\circledR}$ Journal of Language Studies, 12(4).

Sari, E. M. P. (2016). Interlingual errors and intralingual errors found in narrative text written by EFL students in Lampung. Jurnal Penelitian Humaniora, 17(2), 87-95. 
Schertz, J., Cho, T., Lotto, A., \& Warner, N. (2015). Individual differences in phonetic cue use in production and perception of a non-native sound contrast. Journal of phonetics, 52, 183-204.

Smith, B. (2001). Learner English: A teacher's guide to influence and other problems. Cambridge, England: Cambridge University Press.

Sridhanyarat, K. (2018). Thai learners' acquisition of L2 collocations: An interlanguage perspective. GEMA Online ${ }^{\circledR}$ Journal of Language Studies, 18(1), 1-21.

Stemberger, J. P. (1989). Speech errors in early child language production. Journal of Memory and Language, 28(2), 164-188.

Wells, J. G. (1962). A study of the formants of the pure vowels of British English Unpublished $\mathrm{Ph} . \mathrm{D}$ thesis, University of London, London, UK. 


\section{APPENDIX}

\section{RATERS' SCORING KEY FOR THE PRODUCTION TEST}

Dear Rater,

Please, look at the following table of RP English vowels, and complete the table that follows to the best of your abilities. First, decide if the vowel sound was pronounced in a native like way or not, and then look at the chart to choose the sound that best represents it and write it down in your table.

\section{Chart of RP English low vowels}

(A sample word is provided next to each symbol)

\begin{tabular}{|l|l|l|l|}
\hline \multicolumn{2}{|c|}{ Front } & \multicolumn{1}{c|}{ Central } \\
\hline High & & & \\
\hline Mid & & & \\
\hline Low & æ(bat) & $\Lambda$ (but) & a: (calm) (pot) \\
\hline
\end{tabular}

Name of participant:

Group:

\begin{tabular}{|c|c|c|c|c|}
\hline \multirow[t]{2}{*}{ No } & \multirow[t]{2}{*}{ The Word } & \multicolumn{2}{|c|}{$\begin{array}{l}\text { Is the vowel produced in a } \\
\text { native like way? }\end{array}$} & \multirow[t]{2}{*}{ What is the vowel produced? } \\
\hline & & Yes & No & \\
\hline 1 & Cap /kæp/ & & & \\
\hline 2 & Hat /hæt/ & & & \\
\hline 3 & Lack /læk/ & & & \\
\hline 4 & Ton $/ \mathrm{t} \wedge \mathrm{n} /$ & & & \\
\hline 5 & Lust /lıst/ & & & \\
\hline 6 & Duck $/ \mathrm{d} \Lambda \mathrm{k} /$ & & & \\
\hline 7 & $\mathrm{Wad} / \mathrm{w} \mathbf{p d} /$ & & & \\
\hline 8 & $\operatorname{Cot} / \mathrm{kpt} /$ & & & \\
\hline 9 & Lock /lpk/ & & & \\
\hline 10 & Heart /ha:t/ & & & \\
\hline 11 & Last/la:st/ & & & \\
\hline 12 & Hard /ha:d/ & & & \\
\hline
\end{tabular}

\section{ABOUT THE AUTHOR}

The author is an assistant professor in the University of Anbar, Education College for Women, English Language Department. He obtained his BA in English Language form the University of Anbar in (1995), MA in English Linguistics from the University of Jordan (2002), and Ph.D. from Universiti Putra Malaysia in (2016). 